\title{
Pembelian Kompulsif Ditinjau dari Kontrol Diri pada Guru Sekolah Dasar
}

\author{
Siti Maskhuroh ${ }^{*}$, Theda Renanita ${ }^{2}$ \\ ${ }^{1}$ Fakultas Psikologi Universitas Ciputra Surabaya \\ ${ }^{1}$ smaskhuroh@gmail.com, ${ }^{2}$ theda.renanita@ciputra.ac.id
}

\begin{abstract}
Teaching is a profession that is vulnerable to stress. One way to relieve stress is to shop. By shopping, negative feelings that teachers experience can be reduced. Such conditions that continuously occur lead to a risk of compulsive buying. A potential factor that may contribute to compulsive buying is self-control. This study aims to determine whether there is a negative relationship between selfcontrol with compulsive buying in teachers of state elementary schools (SDN). The research is quantitative with correlational design. Pearson product moment was used to analyze the data. Data collection was done using two scales, namely Compulsive Buying Scale and Scale of Self-control. This research was conducted at Elementary Schools $A, B$, and $C$ in Tangerang. The sampling technique used in this study was total population sampling, meaning everyone of the 46 teachers in the three schools became research participants. The test result showed that there is a negative correlation between self-control with compulsive at three state elementary schools $(r=-0.419 \rho=0.002)$.
\end{abstract}

Keywords : compulsive buying, self-control, teacher of Elementary School

Abstrak. Guru termasuk salah satu profesi yang rentan mengalami stres. Salah satu cara untuk menghilangkan stres yaitu dengan berbelanja. Dengan berbelanja perasaan negatif yang dialami guru dapat berkurang. Kondisi demikian yang berkelanjutan berisiko membuat guru mengalami pembelian kompulsif. Salah satu faktor yang diduga berperan terhadap pembelian kompulsif adalah kontrol diri. Penelitian ini bertujuan untuk mengetahui apakah ada hubungan negatif antara kontrol diri dengan pembelian kompulsif pada guru Sekolah Dasar Negeri (SDN). Metode yang digunakan yaitu penelitian kuantitatif dengan desain korelasional. Uji analisis yang digunakan adalah uji korelasi pearson products moment untuk menganalisis data. Pengumpulan data dilakukan dengan menggunakan skala Skala Pembelian Kompulsif dan Skala Kontrol Diri. Penelitian ini dilakukan di SDN A, B, dan C Kab. Tangerang. Teknik sampling yang digunakan yaitu total population sampling, yang berarti seluruh guru di ketiga sekolah yang berjumlah 46 orang menjadi partisipan penelitian ini. Hasil uji korelasi menunjukkan adanya hubungan negatif antara kontrol diri dengan pembelian kompulsif pada guru Sekolah Dasar Negeri $(r=-0.419 \mathrm{Q}=0.002)$.

Kata Kunci: guru, kontrol diri, pembelian kompulsif, Sekolah Dasar Negeri (SDN)

Perilaku konsumen merupakan ranah yang menarik diteliti. Salah satunya adalah perilaku pembelian. Perilaku pembelian tidak pernah lepas dari perilaku sehari-hari. Akan tetapi ternyata perilaku pembelian dapat menimbulkan konsekuensi negatif bagi individu bersangkutan. Perilaku pembelian tersebut adalah pembelian kompulsif. Pembelian kompulsif yaitu perilaku individu ketika melakukan aktivitas berbelanja berulang yang disebabkan adanya suatu hal yang tidak menyenangkan atau akibat dari 
adanya perasaan atau emosi negatif (Faber \& O'Guinn, 1989).

Menurut hasil survei Faber dan O'Guinn (1992) terdapat sekitar 8\% pembeli merupakan pembeli kompulsif. Hasil survei Hassay dan Marcolm (1996) menunjukkan adanya peningkatan presentasi pembeli kompulsif sebesar $4 \%$ yakni naik dari $12 \%$ menjadi 16\%. Dittmar (2005) melakukan survei di negara maju. Sekitar 1 sampai $10 \%$ orang dewasa di negara-negara maju diklasifikasikan sebagai pembeli kompulsif. Di negara Asia, seperti Cina dan Thailand juga mengalami hal yang serupa. Sebanyak 19\% jumlah responden di Cina dan 25\% dari jumlah respoden di Thailand yaitu pembeli kompulsif. Di Indonesia sendiri belum diketahui secara pasti berapa jumlah pembeli yang kompulsif.

Guru sebagai sosok yang bertanggung jawab terhadap muridnya di sekolah menjadi salah satu pekerjaan yang memiliki tingkat stress tertinggi (Angelberta, 2011). Salah satu cara untuk mengurangi stress tersebut adalah dengan berbelanja. Kegiatan tersebut dapat mengarah pada pembelian kompulsif (Hartston \& Pyla, 2012).

Neuner, Raab, dan Reisch (2005) menjelaskan bahwa stres merupakan salah satu faktor individu melakukan pembelian kompulsif. Penelitian Faber dan Christenson (1996) menunjukkan bahwa 91.7\% pembelian kompulsif disebabkan karena mengalami gangguan suasana hati dan sebanyak $78.3 \%$ disebabkan oleh kecemasan. Sementara itu, penelitian Faber dan O'Guinn (1989) mengatakan pembelian kompulsif disebabkan oleh adanya gangguan kepribadian. Faber dan O'Guinn
(1989) memaparkan bahwa konsumen yang kompulsif sering kali melakukan pembelian sebagai kompensasi terhadap suatu keadaan yang tidak menyenangkan dan harga diri yang rendah.

Peristiwa yang tidak menyenangkan tersebut dapat berasal dari faktor internal maupun eksternal individu (Faber \& O'Guinn, 1989). Kedua faktor ini dapat mempengaruhi individu melakukan pembelian kompulsif. Yang termasuk ke dalam faktor eksternal yaitu struktur keluarga (Roberts, 1998), kepemilikan kartu kredit (Park \& Burns, 2005), pengaruh teman pergaulan (Roberts \& Jones, 2001), dan informasi dari media seperti iklan (Dittmar, 2005). Sedangkan yang termasuk ke dalam faktor internal individu melakukan pembelian kompulsif yaitu stress (Faber \& O'Guinn, 1989), frustrasi, kurangnya harga diri (Roberts dan Jones, 2001), kecewa (Gunawan, 2014), dan gangguan otonomi.

Menurut Workman dan Paper (2010), perilaku pembelian kompulsif mempunyai dua konsekuensi, yaitu konsekuensi jangka pendek dan konsekuensi jangka panjang. Konsekuensi jangka pendek bentuknya dapat bersifat positif yaitu pengurangan stres dan ketegangan (Rindfleisch, Burroughs, \& Denton, 1997), peningkatan konsep diri (Faber \& Christenson, 1996) serta peningkatan hubungan interpersonal (Faber \& O'Guinn, 1992). Sedangkan konsekuensi jangka panjang pada umumnya lebih merugikan, secara ekonomi maupun psikologis. Kerugian yang dimaksud yaitu tingginya tagihan kartu kredit, meningkatnya hutang, rendahnya angka 
tabungan, terjerat kasus hukum, adanya perasaan rendah diri, munculnya rasa bersalah, depresi, cemas, frustasi dan mulai munculnya konflik interpersonal (Roberts, 1998).

Benson (2000) menjelaskan bahwa perilaku pembelian kompulsif juga dapat memberikan efek negatif pada kehidupan seseorang. Individu yang memiliki kecenderungan pembelian kompulsif cenderung memiliki hutang yang banyak, dan mengalami kesulitan menabung dikarenakan semua pendapatan yang diperoleh akan habis untuk membeli sejumlah barang (Benson, 2000). Perilaku pembelian kompulsif tidak hanya berpengaruh terhadap masalah finansial seseorang namun juga dapat mengakibatkan penyakit psikologis dan sosial (Faber dan O'Guinn, 1989). Penyakit psikologis dan sosial merupakan dampak dari perasaan negatif yang dirasakan dan digolongkan sebagai perilaku kompulsif (Faber \& O'Guinn, 1989).

Salah satu upaya mengurangi emosi negatif yang dialami para guru adalah dengan berbelanja. Kegiatan belanja yang dilakukan guru tentu difasilitasi oleh pemberian tunjangan profesi guru. Pemberian tunjangan guru ini bertujuan untuk menyejahterakan guru (Anshari, 2015). Tunjangan profesi ini yang kemudian digunakan para guru untuk berbelanja. Kegiatan berbelanja ini dianggap sebagai kegiatan rekreasional. Berbelanja atau berkeliling dari satu toko ke toko lain menimbulkan perasaan senang (Saraneva \& Sääksjärvi, 2008). Dengan berbelanja perasaan negatif atau stress yang sedang dirasakan dapat berkurang.
Dalam penelitian ini, salah satu faktor yang diduga berhubungan dengan pembelian kompulsif adalah kontrol diri. Baumeister dalam Naomi dan Iin (2008) mendefinisikan kontrol diri sebagai kemampuan untuk memberikan respon tertentu terhadap stimulus yang ada. Pendapat lain mengenai kontrol diri diungkapkan oleh Rothbaum, Weisz, dan Snyder (1982) yang mengatakan bahwa kontrol diri yaitu kapasitas individu untuk mengubah atau menyesuaikan diri sehingga menjadi lebih baik dan seimbang antara dunia dengan dirinya.

Menurut Goleman (2005), kontrol diri merupakan kemampuan untuk mengendalikan diri dari emosi yang mencolok. Kontrol diri diperlukan untuk membantu individu mengatasi hal-hal yang berasal dari luar yang dapat merugikan diri sendiri (Ghufron \& Risnawati, 2011). Menurut Tajiri (2012) kemampuan kontrol diri berpegang pada pikiran sadar yang dimiliki oleh manusia. Pikiran sadar tersebut merupakan tingkat kesiagaan individu terhadap stimulus eksternal maupun internal. Peneliti berasumsi guru yang memiliki kontrol diri yang kuat dapat mengendalikan dirinya dalam berbelanja. Sehingga, pembelanjaan yang dilakukannya atas dasar kebutuhan bukan emosi saja. Sebaliknya, guru yang memiliki kontrol diri rendah akan rentan mengalami pembelian kompulsif. Pembelian yang dilakukan bukan atas dasar kebutuhan namun karena dorongan untuk mengurangi stresnya.

Beberapa penelitian terdahulu tentang pembelian kompulsif di Indonesia terbatas pada variabel penggunaan kartu kredit (Ming, Teoh, Chong, \& Yong, 2013), 
struktur keluarga dan nilai matrealistis (Rindfleisch, Burroughs, Denton, 2016), dan sikap terhadap uang (Hanley \& Wilhelm, 1992). Oleh karena itu peneliti ingin meneliti hubungan antara kontrol diri dengan pembelian kompulsif pada guru Sekolah Dasar Negeri. Hasil penelitian ini diharapkan dapat memberi kontribusi dalam mengembangkan ilmu pengetahuan psikologi khususnya yang terkait dengan pembelian guna mengurangi resiko yang ditimbulkan oleh pembelian kompulsif. Bagi guru, penelitian ini dapat memberikan gambaran mengenai perilaku pembelian kompulsif ditinjau dari kontrol diri.

\section{Metode}

Ada dua variabel yang diteliti yaitu kontrol diri sebagai variabel bebas dan pembelian kompulsif sebagai variabel tergantung. Hipotesis penelitian ini yaitu ada hubungan antara kontrol diri dan pembelian kompulsif pada guru Sekolah Dasar Negeri (SDN) di Kab. Tangerang.

Penelitian ini menggunakan teknik kuantitatif dengan metode survei. Variabel kontrol diri diukur menggunakan Skala Kontrol Diri yang diadaptasi dari skala yang disusun oleh Tangney, Baumeister, dan Boone (2004) sedangkan variabel pembelian kompulsif diukur dengan menggunakan skala yang diadaptasi dari skala yang dikembangkan oleh Faber dan O'Guinn (1989). Skala kontrol diri terdiri dari 36 aitem dengan koefisien Alpha Cronbach $\alpha=0.890$, setelah dilakukan uji reliabilitas dengan jumlah responden 30 orang maka didapat koefisien Alpha Cronbach $\alpha=0.816$. Skala pembelian kompulsif terdiri dari 7 aitem dimana total aitem sebelumnya yaitu 14 aitem, dengan koefisien Alpha Cronbach, $\alpha=0.870$ yang telah digunakan sebelumnya oleh Phau dan Woo (2008). Setelah dilakukan uji reliabilitas oleh peneliti, maka diperoleh koefisien reliabilitas Alpha Cronbach, $\alpha=$ 0.701 .

Setelah dilakukan uji coba skala, peneliti melakukan pengambilan data dengan teknik total population sampling. Responden penelitian ini yaitu guru Sekolah Dasar Negeri (SDN) A, B, dan C di Kab. Tangerang yang berjumlah 46 responden. Seluruh responden berasal dari sekolah yang berbeda yakni sebanyak 13 responden berasal dari SDN A, 11 responden dari SDN B, dan 22 responden dari SDN C.

Sebelum melakukan analisis data, peneliti melakukan uji normalitas. Uji normalitas dilakukan menggunakan Kolmogorov Smirnov, didapat nilai Q $=0.200$ dengan nilai kolmogorov smirnov 0.084. Nilai kolmogorov smirnov tersebut menunjukkan bahwa data terdistribusi normal.

\section{Hasil}

Pada bagian ini penulis akan memaparkan hasil penelitian ini. Hasil menunjukkan bahwa hipotesis bahwa terdapat hubungan negatif antara kontrol diri dengan pembelian kompulsif pada guru Sekolah Dasar Negeri (SDN) A, B, dan C $(r=-0.419 p=0.002)$ terbukti. Meski demikian, penulis akan memulai memaparkan hasil ini dengan data demografi dari 46 responden yang dapat dilihat pada Tabel 1 : 
Tabel 1

Deskripsi demografi subjek ( $N=46)$

\begin{tabular}{lcc}
\hline Demografi & $\begin{array}{c}\text { Jumlah } \\
\text { (n) }\end{array}$ & $\begin{array}{c}\text { Presentase } \\
(\%)\end{array}$ \\
\hline Jenis kelamin & & \\
$\quad$ Laki-laki & 13 & 28,3 \\
$\quad$ Perempuan & 33 & 71.7 \\
$\quad$ Total & 46 & 100 \\
Status & & \\
pernikahan & & \\
$\quad$ Menikah & 42 & 91.3 \\
$\quad$ Belum & 3 & 6.5 \\
menikah & & \\
$\quad$ Bercerai & 1 & 2.2 \\
$\quad$ Total & 46 & 100 \\
Status & & \\
pekerjaan & & \\
$\quad$ PNS & 14 & 30.4 \\
$\quad$ Honorer & 32 & 69.6 \\
$\quad$ Total & 46 & 100 \\
\hline
\end{tabular}

Hasil analisis terhadap rata-rata dan standar deviasi masing-masing variabel dapat dilihat pada Tabel 2 berikut :

\begin{tabular}{|c|c|c|}
\hline \multicolumn{3}{|c|}{ Hasil Deskriptif Perolehan Kontrol Diri dan } \\
\hline \multicolumn{3}{|c|}{ Pembelian Kompulsif } \\
\hline Variabel & Rata-rata & Standar Deviasi \\
\hline Kontrol Diri & 3.390 & 0.234 \\
\hline Pembelian & 2.553 & 0.484 \\
\hline Kompulsif & & \\
\hline
\end{tabular}

Tabel 2 menunjukkan deskriptif nilai rata-rata dan standar deviasi pada variabel kontrol diri dan pembelian kompulsif. Variabel kontrol diri memiliki rata-rata sebesar 3.390 dengan standar deviasi sebesar 0.234. Sedangkan variabel pembelian kompulsif memiliki rata-rata sebesar 2.553 dengan standar deviasi sebesar 0.484 .
Hasil analisis korelasional menunjukkan $\mathrm{r}=-0.419$ dan $\mathrm{p}=0.02$ $(p<0.05)$. Dengan demikian maka terdapat hubungan negatif antara kontrol diri dengan pembelian kompulsif pada guru Sekolah Dasar Negeri (SDN) A, B, dan C di Kabupaten Tangerang.

Hasil tabulasi silang antara variabel pembelian kompulsif dengan jenis kelamin seperti pada Tabel 3 berikut:

\begin{tabular}{|c|c|c|c|c|c|c|}
\hline \multicolumn{7}{|c|}{$\begin{array}{l}\text { Tabel } 3 \\
\text { Tabulasi silang variabel pembel } \\
\text { kompulsif dengan jenis kelamin }(\mathrm{N}=46)\end{array}$} \\
\hline \multirow{2}{*}{ Kategori } & \multicolumn{2}{|c|}{ Laki-laki } & \multicolumn{2}{|c|}{ Perempuan } & \multicolumn{2}{|c|}{ Total } \\
\hline & $\mathrm{N}$ & $\%$ & $\mathrm{~N}$ & $\%$ & $\mathrm{~N}$ & $\%$ \\
\hline Sangat & 0 & 0 & 3 & 6.5 & 3 & 6.5 \\
\hline \multicolumn{7}{|l|}{ Rendah } \\
\hline Rendah & 7 & 15.2 & 15 & 32.6 & 22 & 47.8 \\
\hline Sedang & 6 & 13.2 & 12 & 26.1 & 18 & 39.1 \\
\hline Tinggi & 0 & 0 & 3 & 6.5 & 3 & 6.5 \\
\hline Sangat & 0 & 0 & 0 & 0 & 0 & 0 \\
\hline \multicolumn{7}{|l|}{ Tinggi } \\
\hline Total & 13 & 28.3 & 33 & 71.7 & 46 & 100 \\
\hline
\end{tabular}

Data Tabel 3 tersebut menunjukkan bahwa sebaran kecenderungan pembelian kompulsif pada responden laki-laki dan perempuan paling banyak berada pada kategori rendah. Pada kelompok responden laki-laki tidak ada responden yang berada pada kategori tinggi dan sangat tinggi. Akan tetapi pada kelompok responden perempuan terdapat $6.5 \%$ responden dengan kecenderungan pembelian kompulsif tinggi. 


\section{Diskusi}

Menurut Angelberta (2011), guru merupakan salah satu pekerjaan yang memiliki tingkat stres tertinggi. Selain bertanggung jawab atas siswa-siswi di sekolah, guru pun turut berhadapan dengan pihak sekolah juga orang tua dari siswa-siswi tersebut. Neuner, Raab, dan Reisch (2005) menjelaskan bahwa stres merupakan salah satu faktor individu melakukan pembelian kompulsif.

Menurut Flokman dan Lazarus (dalam Sarafino dan Smith, 2011) ada dua bentuk klasifikasi cara mengurangi perasaan negatif yang timbul yaitu, problem focused dan emotion focused. Sesuai dengan namanya, problem focused merupakan cara mengurangi stres dengan lebih mengarah pada upaya mengurangi tuntutan atau situasi yang ada. Biasanya individu yang memilih untuk problem focused merupakan individu yang memiliki kontrol diri yang tinggi. Karena individu dengan kontrol diri tinggi akan lebih mementingkan tuntutan atau situasi yang ada. Cara mengurangi stres lainnya yaitu emotion focused berarti guru tersebut lebih berfokus untuk mengurangi emosi yang timbul akibat tekanan yang sedang dihadapi. Sebagai respon terhadap stress yang dialami, berbelanja menjadi salah satu alternatif yang dilakukan oleh guru. Menurut Hartston dan Pyla (2012), aktivitas berbelanja dapat membuat seseorang rentan mengalami pembelian kompulsif.

Terkait pembelian kompulsif, hasil penelitian ini menunjukkan jika seseorang yang memiliki kontrol diri tinggi maka kecenderungan melakukan pembelian kompulsif rendah. Demikian sebaliknya, semakin rendah kontrol diri maka kecenderungan melakukan pembelian kompulsif akan tinggi. Individu dengan kontrol diri yang tinggi memiliki kemampuan yang lebih baik dalam mengendalikan pikiran, emosi, kinerja, serta perhatian individu dibanding dengan individu yang memiliki kontrol diri rendah (Baumeister, Bratslavsky, Muraven \& Tice, dalam DeRidder, Lensvelt-Mulders, Finkenauer, Stok, \& Baumeister, 2011).

Pada saat guru mengalami kondisi tekanan karena tugasnya, serta memiliki kontrol diri yang rendah maka guru akan cenderung untuk mencari kegiatan lain untuk meringankan tekanan yang ada. Aktivitas yang menyenangkan ini salah satunya yaitu dengan melakukan pembelian. Kegiatan berbelanja tersebut membuat perasaan negatif guru berkurang. Oleh karena itu, perilaku belanja cenderung terjadi berulang yang kemudian dikenal dengan pembelian kompulsif. Guru yang mampu mengelola dorongan dari dalam dirinya untuk berbelanja dapat terhindar dari pembelian kompulsif.

Penelitian ini sejalan dengan penelitian Naomi dan Iin (2008) yang menjelaskan bahwa kontrol diri berpengaruh negatif terhadap perilaku kompulsif. Pembelian kompulsif terjadi dikarenakan faktor psikologis konsumen yaitu rendahnya kontrol diri. Hal tersebut mampu dicegah apabila konsumen mampu mengendalikan dirinya sendiri. Jika konsumen mampu mengendalikan dirinya sendiri berarti konsumen tersebut memiliki kontrol diri yang tinggi maka ia mampu menggunakan logika rasional dalam mengambil keputusan pembelian. 
Berbagai tekanan yang muncul sebagai konsekuensi dari pekerjaan guru memicu guru untuk menyelesaikannya. Belanja menjadi alternatif yang dapat dilakukan di tengah kesibukannya tersebut. Melalui belanja seseorang dapat memperoleh kenikmatan. Dalam kesehariannya, guru terpapar berbagai iklan maupun promo yang mendorongnya melakukan proses pembelian. Akan tetapi, guru yang memiliki kontrol diri yang kuat memiliki kecenderungan yang rendah untuk mengalami pembelian kompulsif.

Kontrol diri diartikan sebagai kemampuan mengelola tingkah laku salah satunya yaitu perilaku pembelian. Orangorang dengan kontrol diri yang rendah mengalami kesulitan mengelola perilaku pembelian mereka. Mereka gagal mengelola informasi produk yang mereka terima. Sebagai dampaknya, mereka memutuskan pembelian secara emosional (Anggreini \& Mariyanti, 2014).

Individu dengan pengendalian diri yang baik cenderung berhemat dan menyimpan uangnya. Mereka memiliki kondisi keuangan yang lebih baik daripada individu dengan pengendalian diri yang rendah. Selain itu mereka memiliki rasa cemas yang rendah pada hal-hal keuangan dan merasa aman secara psikologis terkait kondisi keuangan saat ini dan yang akan datang (Strömbäck, Lind, Skagerlund, Västfjäll, \& Tinghög, 2017).

Hasil tabulasi silang antara jenis kelamin dengan pembelian kompulsif menunjukkan bahwa dari 46 responden terdapat 3 responden perempuan dengan kecenderungan pembelian kompulsif tinggi. Pada penelitian yang dilakukan oleh
Mc Elroy, Keck, Pope, Smith, \& Strakowski (1994) yang menunjukkan bahwa $80 \%$ sampai $95 \%$ dari pembeli kompulsif yaitu perempuan. Penelitian lain yang dilakukan oleh Dittmar (2005) menjelaskan bahwa $92 \%$ dari hasil survei yang dilakukan di Inggris pembeli kompulsif yaitu perempuan. Faber dan O'Guinn (1989) menemukan hasil yang serupa bahwa $90 \%$ pembeli kompulsif yaitu perempuan. Secara sosial, salah satu tugas perempuan yaitu berbelanja kebutuhan rumah tangga. Seperti dikatakan oleh Shoham dan Brencic (2003) wanita cenderung untuk melakukan pembelian kompulsif dikarenakan peran mereka sebagai ibu rumah tangga yang mengurusi segala keperluan rumah tangga. Block dan Morwitz (1999) juga menghubungkan tugas seorang wanita yaitu wanita bertanggung jawab atas belanja bahan makanan, lebih mengetahui mengenai produk dan toko, serta wanita lebih baik dalam mengatur persediaan bahan belanjaan dibanding laki-laki.

Aktivitasnya berbelanja menjadikan perempuan rentan terpapar berbagai informasi produk (Scherhorn, Reisch, \& Raab, 1990). Menurut Faber dan O'Guinn (1989), perempuan lebih terbuka terhadap informasi tentang belanja. Black (2007) mengatakan jika perempuan menikmati kegiatan belanja tersebut.

Peran sosial perempuan menjadikan perempuan mengembangkan cara yang pasif namun emosional ketika menghadapi stress dan konflik. Mereka memiliki kecenderungan menyelesaikan masalahnya dengan diam-diam melalui kegiatan belanjanya. Kegiatan belanja ini dipilih 
karena kegiatan ini diterima secara sosial (Scherhorn, Reisch, \& Raab, 1990).

\section{Kesimpulan}

Berdasarkan hasil penelitian ini maka dapat disimpulkan bahwa ada hubungan negatif antara kontrol diri dengan pembelian kompulsif pada guru Sekolah Dasar Negeri (SDN). Tanda minus pada koefisien korelasi menunjukkan jika semakin tinggi kontrol diri yang dimiliki oleh guru tersebut maka akan semakin rendah kecenderungan pembelian kompulsif. Sebaliknya, semakin rendah kontrol diri seorang guru SDN maka semakin tinggi pembelian kompulsif. Melalui hasil riset ini maka salah satu upaya untuk mengurangi masalah finansial yang disebabkan karena pembelian kompulsif. Hasil penelitian ini dapat digunakan oleh para konsultan keuangan dalam mengelola dan merencanakan keuangan terutama para guru. Sementara itu para guru dapat menjadikan hasil penelitian ini sebagai informasi bahwa kontrol diri dapat mempengaruhi kecenderungan pembelian kompulsif mereka.

\section{Daftar Pustaka}

Angelberta (14 Agustus 2011). 10 Jenis Pekerjaan yang Menyebabkan Stres Tingkat Tinggi. Diakses dari http://sidomi.com/14326/10-jenis-pekerjaanyang-menyebabkan-stres-tingkat-tinggi/ tanggal 13 Agustus 2016.

Anggreini, R., \& Mariyanti, S. (2014). Hubungan antara kontrol diri dan perilaku konsumtif. Jurnal Psikologi, 12(1), 1-9.
Anshari (24 November 2015). Revolusi mental guru. Diakses http://makassar.tribunnews.com/2015/11/24 /revolusi-mental-guru tanggal 27 November 2016.

Benson, H.M.D. (2000). Dasar-dasar respon relaksasi : bagaimana menggabungkan respon relaksasi dengan keyakinan pribadi anda (terjemahan). Bandung: Mizan.

Black, D. W. (2007). A Review of compulsive buying disorder. World Psychiatry, 6(1), 14-18.

Block, L.G. \& Morwitz, V.G. (1999). Shopping lists as an external memory air for grocery shopping : Influences on list writing and fulfillment. Journal of Consumer Psychology, 8(4), 343-375.

DeRidder, T., Lensvelt-Mulders, G., Finkenauer, C., Stok, F. M., \& Baumeister, R. F. (2011). Taking stock of self-control: A meta analysis of how trait self-control relates to a wide range of behaviors. Personality and Social Psychology Review, 124.

Dittmar, H. (2005). Compulsive buying - a growing concern? An examination of gender, age, and endorseement of materialistic values as predictors. British Journal of Psychology, 96, 467-491.

Faber, R.J., \& Christenson, G. A. (1996). In the mood to buy: Differences in the mood states experienced by compulsive buyers and other consumers. Psychology $\mathcal{E}$ Marketing, 13(8), 803-819.

Faber, R. J., \& O'Guinn, T. C. (1989). Classifying compulsive consumers: advances in the development of a diagnostic tool. Advances in Consumer Research, 16(1), 738-744.

Ghufron, M.N \& Risnawati, R. (2011). Teoriteori psikologi. Jogyakarta: ArRuzz Media. 
Goleman, D. (2005). Emotional intelligence. Jakarta: Gramedia.

Gunawan, Adi, P,. (21 April 2014). Memahami Emosi. Diakses dari Http://adigunawan.com/articles/memahami -emosi tanggal 10 Juni 2016

Hartston, R., \& Pyla, P. S. (2012, Mei 8). The wheel: A lifecycle template. The UX book: Process and guidelines for ensuring a quality user experience. Diunduh dari https://medium.com/the-ux-book-hartsonpyla-review/2f505ba01472 tanggal $10 \mathrm{Mei}$ 2016.

Hanley, A., \& Wilhelm, M. S. (1992). Compulsive buying: An exploration into self-esteem and money attitudes. Journal of Economic Psychology, 13, 5-18.

Hassay, D.N. \& Marcolm, C.S. (1996). Compulsive buying: An examination of the consumption motive. Psychology $\mathcal{E}$ Marketing, 13(8), 741 - 756.

Kurniawa, Floretine Yovita dan Gede Suparna. (2012). Peran kepemilikan kartu kredit dalam memoderasi pengaruh kontrol diri dan atmosfer gerai terhadap perilaku belanja kompulsif konsumen pakaian di Kuta. Jurnal Ekonomi, 1685 -1699.

Ming, W., Teoh, Y., Chong, S.-C., \& Yong, M. S. (2013). Exploring the factors influencing credit card spending behavior among Malaysians. International Journal of Marketing, $\quad 31(6), \quad 481-500$. https://doi.org/10.1108/IJBM-04-2013-0037

Naomi, P. \& Iin, M. (2008). Pengaruh kontrol diri terhadap perilaku pembelian kompulsif. Telaah Bisnis, 9. 179-193.

Neuner, M., Raab, R., \& Reisch, L.a (2005). Compulsive buying in maturing konsumer Societies: An emirical re-inquiry. Journal of Economic Psychology, 26, 509 - 522.
Mc Elroy, S. L., Keck, P. E., Pope, H.G., Smith, J. M., \& Strakowski, S. M. (1994). Compulsive buying: a report of 20 cases. The Journal of Clinical Psychiatry, 55(6), 242248.

Park, J. H. \& Burns, D. (2005). Fashion orientation, credit card use, and compulsive buying: A phenomenological exploration. Journal of Consumer Marketing, 22(3), 135141.

Phau, I. \& Woo, C. (2008). Understannding compulsive buying tendencs pamong young Australians: The roles of money attitude and credit card usage. Journal Marketing Intelligences \& Planning, 26(5), 441 -458 .

Rindfleisch, A., Burroughs, J. E., \& Denton, F. (2016). Family structure, materialism, and compulsive consumption. Journal of Consumer Research, 23(4), 312-325.

Roberts, J.A. (1998), Compulsive buying among college students : An investigation of its antesedents, consequences, and implications for public policy. The Journal of Consumer Affairs, 32 (2), 295-319.

Robert, J.A. \& Jones, E. (2001). Money attitudes, credit card use, and compulsive buying among American college students, The Journal of Consumer Affairs, 35(21), 45-58.

Rothbaum, F., Weisz, J. R., \& Snyder, S. S. (1982). Changing the world and changing the self: A two-process model of perceived control. Journal of Personality and Social Psychology, 42(1), 5-37.

Sarafino, E. P., \& Smith, T. W. (2011). Health psychology : Biopsychosocial interactions (7th ed.). United States of America: John Willey \& Sons Inc.

Saraneva, A., \& Sääksjärvi, M. (2008). Young compulsive buyers and the 
emotional roller-coaster in shopping. Young Consumers, 9(2), 75-89. https://doi.org/10.1108/17473610810879657

Shoham, A. \& Brencic, M.M. (2003). Compulsive buying behavior. Journal of Consumer Marketing, 20(2), 127 - 138.

Scherhorn, G., Reisch, L. A., \& Raab, G. (1990). Addictive buying in West Germany: An empirical study. Journal of Consumer Policy, 13(4), 355-387. https://doi.org/10.1007/BF00412336

Strömbäck, C., Lind, T., Skagerlund, K., Västfjäll, D., \& Tinghög, G. (2017). Does self-control predict financial behavior and financial well-being? Journal of Behavioral and Experimental Finance, 14, 30-38. https://doi.org/10.1016/j.jbef.2017.04.002.

Tajiri, H. (2012). Model konseling kognitifperilaku untuk meningkatkan kemampuan kontrol diri perilaku seksual remaja. (Disertasi yang tidak diterbitkan) Universitas Pendidikan Indonesia, Bandung.
Tangney, J. P., Baumeister, R. F., Boone, A.L. (2004). High self-control predicts good adjustment, less pathology, better grades, and interpersonal success. Journal of Personality, 72(2), 272-320.

Workman, L., \& Paper, D. (2010). Compulsive buying: Theoretical framework. 2010. The Journal of Business Inquiry, 9(1), 89-12

Ming, W., Teoh, Y., Chong, S.C., \& Yong, M. S. (2013). Exploring the factors influencing credit card spending behavior among Malaysians. International Journal of Marketing, $\quad 31(6), \quad 481-500$. https://doi.org/10.1108/IJBM-04-2013-0037 